\title{
Relics and Kindling: An Autobiography
}

I can't understand you when you mumble, my father would say, and look, I've spent my entire life mumbling.

The random details equal the whole of our attention to them: our delight in connections, our tedium at the impasse; our delight at the impasse, our tedium in the connections.

High in the maple amid the keys and the wind, I'd sway as the branch tipped, tossed, shivered and swooned, and if not for my grip, the gray bark against my cheek, the tether of gravity and my own fear of heights, I swear I flew: above the housetops and the field, above the gully flooded with runoff, the spiral of swifts (for years I thought they were bats) lifting from the incinerator's brick chimney, above the powder blue water tower, a tear-mark of rust beneath each rivet, above the grain elevators of North Kansas City and the wide Missouri, above the barges and high tension wires, above the bluffs and scree, and flying, my body was my own-not a changeling's body, hollow-boned, not a projection against a screen, not a fall from which I would wake to a thud on box-springs-the shuddered fabric of my windbreaker caught a gust like a sail as I stepped out onto the air and for a moment dropped like the swifts as they bob and swoop down and downward, only to shoot up and out of sight.

Awake, I would listen for the inchoate static on the crystal set.

The Christmas candle gutters between ravel and weave, between the invention and obsolescence of zero.

My father's ashes are in a jar in my sister's toolshed.

The poem as the duration of the act. 
Over the harvested fields, the rain-wet marl of shadow clear to the stubble-frayed edge, the owl, rose-flecked by a cloud-smeared moon, as swift as the soul taking its leave, plunges down through the ruin: How else can a body stay alive, but to fall and rise as flesh: consumed, consuming, with brute relish.

I hung out at a Jesus Freak's coffee house. The House of Agape. Each night we were surprised and more than a little disappointed that the Rapture had not come. The coffee was awful, but the talk as hopeful as it must be on Death Row with appeal after appeal ahead. One night a nurse started speaking in tongues. She fell to the linoleum floor as if in a seizure, her right foot clanging against a metal folding chair, one of her garters unsnapped and danced on the white flesh of her upper thigh. After that night, I did not return.

The moth-eaten lacework of the moon, a dream's calculus, inscribed yet unutterable, beyond solution.

The rhythm as an embrace.

When I asked where that was, he said, My town is as far away from the next as near to anything.

My father sitting on the edge of his bed, his back to the door. Elbows on his knees. Head in his hands. Fully clothed. He will wait until morning to rise and again go to work. This is how I remember him. On the edge of his bed. Back to the door. If he were not so still, I'd swear he was sobbing.

She said, Oh, you mean the experience of white and not the theory of white. He said, Yes, as in a journal, a map of days, the parts segregated, yet opening into one another. She said, For want of words you might just consider an idea for a poem. He said, On Memorial Day we decorated the graves of the war dead with flowers and little paper flags that the sun would bleach into flags of surrender. She said, Now that you are your father, you no longer have to carry his 
broken body in your arms. He said, I remember those boys who broke the hive with a baseball bat and how the bees swarmed on the power line and the transformer. He said, I admire the way my dog can make sense of the world by its stink. She said, My sign is the gazelle in a thicket. Yours is the bull in a quagmire. She said, You should give the beggars what they ask for and thank them. 